\title{
Chemical and Nutritional Composition of Some Common Foods in Abeokuta, Nigeria
}

\author{
Silifat Ajoke Sanni ${ }^{1}$, Clara Raquel Bernstein Oguntona ${ }^{1 *}$ and Lateef Oladimeji Sanni $^{2}$ \\ ${ }^{1}$ Department of Home Science and Management, College of Agricultural Management, Rural Development and \\ Consumer Studies, University of Agriculture, PMB 2240 Abeokuta; ${ }^{2}$ Food Science and Tech Department, University \\ of Agriculture, Abeokuta, Nigeria
}

\begin{abstract}
Chemical composition of seven common foods viz. cooked rice, cooked beans, cooked yams, cooked fufu, fried fish, stew, and vegetable soup, sold by the selected (147) vendors in Abeokut, were investigated. Descriptive statistics was used to analyse the collected data. The results of the proximate analysis of food samples showed that the mean moisture content of the street foods ranged from $44.87 \%$ in fried fish to $72.43 \%$ in cooked fufu. Protein content varied from $0.03 \%$ in cooked fufu to $14.47 \%$ in fried fish while the fat content ranged from $0.03 \%$ in cooked fufu to $34.43 \%$ in fried fish. Ash and carbohydrate contents ranged from $0.42 \%$ in cooked rice to $16.07 \%$ in vegetable soup and $0.73 \%$ in stew to $29.27 \%$ in cooked rice, respectively. The energy content ranged from 89.0 Kcal in cooked fufu to $375.24 \mathrm{Kcal}$ in fried fish. In general, fried fish had the highest values of protein (14.47\%), fat (34.43\%) and energy content $(375.24 \mathrm{KCal}$.). The results showed that there were no appreciable differences in the proximate composition of the selected foods across the locations.
\end{abstract}

Keywords: Chemical and nutritional composition, common foods, Abeokuta, Nigeria

\section{INTRODUCTION}

Current estimates on urban populations suggest that by the year 2000 the urban population of less developed countries will increase by 600 million and that as many as 2 billion people will be added to urban populations from the year 2000-2025 (FAO, 1997). This growth in urban populations and the subsequent increase in the demand for food in urban areas are certainly one of the great challenges of the near future. Amongst others, the informal food sector-also called street foods-has a role to play in providing reliable, accessible and nutritious food for urban areas. Street foods are defined as ready-to-eat foods and beverages prepared and /or sold by vendors and hawkers in the open air in streets and other public places (FAO, 1997; Addo, 1998).

Despite its tremendous potential to improve both nutrition and food security among urban populations, street foods sometimes causes concern with respect to their potential for serious food poisoning outbreaks due to microbiological contamination, improper, use of additives and the presence of other adulterants and environmental contamination (FAO, 1995).

This study is part of wider enquiry into the contribution of street foods to the food and nutrient intake of the community that started in 1995 (Oguntona and Kanye, 1995; Oguntoma et. al., 1998). However, the chemical compositions of such foods were not reported. The present study therefore aims at the nutrient content of some selected street foods sold in Abeokuta.

\section{MATERIALS AND METHODS}

Selection of study area: For the purpose of this study, seven areas were purposively selected. The selection was based on the extent of commercial activities taking place in these areas. In all, four locations were selected in Abeokuta South while three locations were selected in Abeokuta North Local Government Areas. This was done due to the fact that Abeokuta South has more commercial centres than Abeokuta North.

\footnotetext{
* Author for correspondence
} 
Selection of vendors: In the selected areas, census of available vendors was carried out within experimental limit. Segregation of vendors based on food items sold was done. From the collated list, three (3) vendors per food sample were systematically selected. In all, a total of 147 vendors were selected.

Collection of food samples: A completely randomized block design was used in the collection of the food samples. This entails randomly collecting different food samples across the zones per trip/day. The food items include cooked yam (Discorea rotundata), cooked fufu (fermented wet paste from cassava), cooked rice, cooked beans, fried fish (sardine), stew and vegetable soups (water leaf). An appropriate portion of the food items was purchased from the vendors and aspetically kept separately in sterile labeled polythene bags, except for vegetable soups and stew samples that were bought into sterile plastic containers. Water samples were aseptically collected into sterile containers from the storage bucket whilst waste-water samples were from washing basin. The collected samples were then transported immediately to the laboratory within the shortest possible time and analysed forthwith.

Chemical analysis: Proximate analysis in terms of moisture content, fat, protein, ash were determined according to AOAC (1980) while the carbohydrate content of samples was obtained in form of difference between 100 and the sum of moisture, protein, fat and ash values (AOAC, 1980).

Energy evaluation: The food energy was calculated from the values of the proximate determination assuming that protein, carbohydrate and fat yield 4, 4, and 9 calories respectively per gram (Iwe and Onuh, 1992).

Data analysis: The values obtained in the proximate and microbiological analysis were collated according to locations and food items.

Average values per each food item and location were determined and analysed using descriptive statistics using SYSTAT Version 5.0. The data obtained were compared with standard values as reported in the literature.

\section{RESULTS AND DISCUSSION}

Proximate composition of cooked rice: The results of the proximate composition of cooked rice at different locations in Abeokuta are shown in Table 1. The result showed that cooked rice composed abundantly of water and carbohydrate. The moisture ranged from $64.46-67.58 \%$ whilst carbohydrate ranged from $28.46-30.73 \%$. The result also showed that tested cooked rice was low in protein and fat content. The crude fat ranged from $1.23-1.73 \%$ whilst protein ranged from $2.22-3.35 \%$. The cooked rice samples were uniform in ash content which ranged from 0.37 $0.43 \%$.

In terms of locations, the highest value of moisture $(67.55 \%)$ and carbohydrate $(30.73 \%)$ contents were found in cooked rice sampled at Sapon/Itoku and Kuto/Isabo respectively. In contrast, the highest value of protein $(3.35 \%)$ and fat $(1.52 \%)$ content were respectively found in samples obtained at Ijaiye/Oke-Ijeun and Mokola/Iberekodo areas. Energy content of cooked rice ranged from 133.71-147.54 KCal and this is quite an appreciable values. From the result, cooked rice can be regarded as a food high in energy but low in protein hence combination of rice with protein rich foods such as animal sources like meat sauces as well as plant sources like pulses will provide fairly good levels of protein.

Across the locations, there were no appreciable differences in the proximate values of the food samples. The little difference observed is due to the reasons that some of the vendors preferred parboiled imported rice whilst local, less parboiled rice (ofada rice) were the choice of other vendors. When questioned on this choice, the vendors other vendors. When questioned on this choice, the vendors claimed that their choice is usually determined by the taste of their customers. This not withstanding, all the different types of cooked rice generally provide almost same nutrient to the body. 
Table 1: Proximate composition (\%) of cooked rice at various locations in Abeokuta

\begin{tabular}{|l|l|l|l|l|l|l|}
\hline \multicolumn{1}{|c|}{ Location } & Moisture & Fat & Protein & Ash & Carbohydrate & $\begin{array}{c}\text { Energy } \\
(\mathrm{KCal})\end{array}$ \\
\hline Asero/Adatan & 64.46 & 0.41 & 3.30 & 0.43 & 30.40 & 47.50 \\
\hline Sapon/Itoku & 67.58 & 0.22 & 2.31 & 0.43 & 28.46 & 34.06 \\
\hline Lafenwa/Itaoshin & 67.53 & 0.36 & 2.22 & 0.37 & 28.52 & 35.20 \\
\hline Isabo/Kuto & 65.44 & 0.73 & 2.73 & 0.41 & 29.69 & 45.25 \\
\hline Omida/Ibara & 67.55 & 0.11 & 2.22 & 0.41 & 28.71 & 33.71 \\
\hline Ijaiye/Okejeun & 66.36 & 0.22 & 3.35 & 0.43 & 28.64 & 38.94 \\
\hline Mokola/Iberekodo & 65.24 & 0.52 & 2.33 & 0.43 & 30.48 & 45.02 \\
\hline Mean & 66.31 & 0.22 & 2.64 & 0.42 & 29.27 & 39.95 \\
\hline Standard deviation & 1.29 & 0.26 & 0.50 & 0.02 & 0.90 & 0.89 \\
\hline
\end{tabular}

Table 2: Proximate composition (\%) of cooked beans at various locations in Abeokuta

\begin{tabular}{|l|l|l|l|l|l|l|}
\hline \multicolumn{1}{|c|}{ Location } & Moisture & Fat & Protein & Ash & Carbohydrate & $\begin{array}{l}\text { Energy } \\
\text { (KCal) }\end{array}$ \\
\hline Asero/Adatan & 69.00 & 0.50 & 11.0 & 0.40 & 16.10 & 112.90 \\
\hline Sapon/Itoku & 69.40 & 0.36 & 11.60 & 0.50 & 16.14 & 114.20 \\
\hline Lafenwa/ Itaoshin & 68.00 & 0.53 & 12.20 & 0.90 & 16.10 & 118.10 \\
\hline Isabo/Kuto & 68.00 & 0.31 & 11.30 & 0.30 & 17.09 & 116.26 \\
\hline Omida/Ibara & 69.00 & 0.45 & 11.00 & 0.40 & 16.15 & 112.65 \\
\hline Ijaiye/Okejeun & 69.40 & 0.50 & 11.65 & 0.80 & 14.65 & 109.85 \\
\hline Mokola/Iberekodo & 69.22 & 0.47 & 12.17 & 0.70 & 14.50 & 110.67 \\
\hline Mean & 68.86 & 0.45 & 11.56 & 0.29 & 15.82 & 113.52 \\
\hline Standard deviation & 0.61 & 0.08 & 0.50 & 0.45 & 0.92 & 2.93 \\
\hline
\end{tabular}

Table 3: Proximate composition (\%) of cooked yam at various locations in Abeokuta

\begin{tabular}{|l|l|l|l|l|l|l|}
\hline \multicolumn{1}{|c|}{ Location } & Moisture & Fat & Protein & Ash & Carbohydrate & $\begin{array}{l}\text { Energy } \\
\text { (KCal) }\end{array}$ \\
\hline Asero/Adatan & 67.42 & 0.31 & 1.83 & 0.16 & 29.28 & 127.73 \\
\hline Sapon/Itoku & 67.25 & 0.33 & 1.85 & 0.14 & 29.43 & 128.09 \\
\hline Lafenwa/Itaoshin & 67.24 & 0.32 & 1.76 & 0.18 & 29.49 & 127.88 \\
\hline Isabo/Kuto & 67.22 & 0.33 & 1.83 & 0.14 & 29.48 & 128.32 \\
\hline Omida/Ibara & 68.22 & 0.35 & 2.23 & 0.16 & 28.06 & 124.13 \\
\hline Ijaiye/Okejeun & 67.23 & 0.33 & 1.73 & 0.18 & 29.56 & 128.01 \\
\hline Mokola/Iberekodo & 67.43 & 0.32 & 2.33 & 0.15 & 28.77 & 127.28 \\
\hline Mean & 67.28 & 0.33 & 1.94 & 0.16 & 29.15 & 127.35 \\
\hline Standard deviation & 1.46 & 0.01 & 0.24 & 0.02 & 25.41 & 1.46 \\
\hline
\end{tabular}

Table 4: Proximate composition (\%) of cooked Fufu at various locations in Abeokuta

\begin{tabular}{|l|l|l|l|l|l|l|}
\hline \multicolumn{1}{|c|}{ Location } & Moisture & Fat & Protein & Ash & Carbohydrate & $\begin{array}{l}\text { Energy } \\
(\mathrm{KCal})\end{array}$ \\
\hline Asero/Adatan & 76.13 & 0.03 & 0.04 & 0.73 & 23.07 & 92.71 \\
\hline Sapon/Itoku & 76.45 & 0.02 & 0.03 & 0.77 & 22.73 & 91.22 \\
\hline Lafenwa/ Itaoshin & 77.78 & 0.03 & 0.02 & 0.00 & 21.17 & 85.03 \\
\hline Isabo/Kuto & 78.43 & 0.01 & 0.03 & 0.92 & 20.61 & 82.65 \\
\hline Omida/Ibara & 76.83 & 0.10 & 0.03 & 0.85 & 22.19 & 98.78 \\
\hline Ijaiye/Okejeun & 76.77 & 0.01 & 0.03 & 0.93 & 22.46 & 90.84 \\
\hline Mokola/Iberekodo & 77.67 & 0.03 & 0.03 & 0.88 & 21.39 & 85.95 \\
\hline Mean & 72.43 & 0.03 & 0.03 & 0.87 & 21.95 & 89.60 \\
\hline Standard deviation & 12.82 & 0.01 & 0.00 & 0.09 & 0.90 & 5.49 \\
\hline
\end{tabular}


Table 5: Proximate composition (\%) of fried fish at various locations in Abeokuta

\begin{tabular}{|l|l|l|l|l|l|c|}
\hline Location & Moisture & Fat & Protein & Ash & Carbohydrate & $\begin{array}{l}\text { Energy } \\
(\mathrm{KCal})\end{array}$ \\
\hline Asero/Adatan & 45.42 & 3.33 & 4.67 & 0.07 & 2.53 & 368.69 \\
\hline Sapon/Itoku & 43.42 & 5.63 & 4.23 & 0.04 & 1.68 & 384.31 \\
\hline Lafenwa/ Itaoshin & 44.63 & 3.47 & 4.55 & 0.07 & 2.28 & 68.57 \\
\hline Isabo/Kuto & 45.40 & 4.52 & 4.55 & 0.08 & 1.45 & 74.68 \\
\hline Omida/Ibara & 44.51 & 4.72 & 4.15 & 0.03 & 2.61 & 79.34 \\
\hline Ijaiye/Okejeun & 45.31 & 4.82 & 4.48 & 0.06 & 1.33 & 76.67 \\
\hline Mokola/Iberekodo & 45.40 & 4.51 & 4.53 & 0.07 & 1.43 & 74.43 \\
\hline Mean & 44.87 & 4.43 & 4.47 & 0.35 & 1.90 & 375.24 \\
\hline Standard deviation & 0.53 & 0.80 & 0.01 & 0.10 & 0.12 & 4.97 \\
\hline
\end{tabular}

Table 6: Proximate composition (\%) of stew at various locations in Abeokuta

\begin{tabular}{|l|l|l|l|l|l|l|}
\hline Location & Moisture & Fat & Protein & Ash & Carbohydrate & $\begin{array}{l}\text { Energy } \\
(\mathrm{KCal})\end{array}$ \\
\hline Asero/Adatan & 71.05 & 8.46 & 1.00 & 0.81 & 0.68 & 172.86 \\
\hline Sapon/Itoku & 72.64 & 7.09 & 1.01 & 0.63 & 0.63 & 160.37 \\
\hline Lafenwa/Itaoshin & 71.67 & 8.06 & 1.02 & 0.66 & 0.59 & 168.98 \\
\hline Isabo/Kuto & 71.93 & 7.38 & 1.02 & 0.81 & 0.86 & 163.94 \\
\hline Omida/Ibara & 72.20 & 9.07 & 1.01 & 0.87 & 0.85 & 161.07 \\
\hline Ijaiye/Okejeun & 72.23 & 7.06 & 1.01 & 0.85 & 0.85 & 160.98 \\
\hline Mokola/Iberekodo & 72.41 & 7.07 & 1.03 & 0.86 & 0.63 & 160.27 \\
\hline Mean & 72.02 & 7.74 & 1.01 & 0.78 & 0.73 & 164.07 \\
\hline Standard deviation & 0.75 & 0.80 & 0.20 & 0.48 & 0.55 & 5.62 \\
\hline
\end{tabular}

Table 7: Proximate composition (\%) of vegetable soups at various locations in Abeokuta

\begin{tabular}{|l|l|l|l|l|l|l|}
\hline Location & Moisture & Fat & Protein & Ash & Carbohydrate & Energy \\
\hline Asero/Adatan & 46.48 & 7.43 & 8.91 & 5.91 & 1.27 & 37.59 \\
\hline Sapon/Itoku & 46.00 & 7.45 & 9.00 & 6.05 & 1.50 & 39.05 \\
\hline Lafenwa/Itaoshin & 45.68 & 7.48 & 9.34 & 6.60 & 1.30 & 39.88 \\
\hline Isabo/Kuto & 45.57 & 7.49 & 9.10 & 5.97 & 1.87 & 41.29 \\
\hline Omida/Ibara & 45.39 & 7.51 & 9.09 & 6.04 & 1.97 & 41.83 \\
\hline Ijaiye/Okejeun & 46.23 & 7.44 & 9.08 & 5.93 & 1.32 & 38.56 \\
\hline Mokola/Iberekodo & 46.92 & 7.45 & 8.54 & 5.98 & 1.11 & 37.65 \\
\hline Mean & 46.04 & 7.46 & 6.41 & 6.07 & 1.48 & 39.41 \\
\hline Standard deviation & 0.54 & 0.03 & 0.10 & 0.24 & 0.32 & 0.68 \\
\hline
\end{tabular}

Table 8: Mean energy and protein values of common foods in Abeokuta

\begin{tabular}{|l|c|c|c|c|}
\hline Foods & Energy (Kcal) & \%RDI* & Protein (\%) & \%RDI* \\
\hline Cooked Rice & 139.95 & 4.7 & 2.64 & 7.1 \\
\hline Cooked Beans & 113.52 & 3.8 & 11.56 & 31.2 \\
\hline Cooked Yam & 127.35 & 4.3 & 1.94 & 5.2 \\
\hline Cooked Fufu & 89.50 & 3.0 & 0.03 & 0.08 \\
\hline Fried Fish & 375.24 & 12.5 & 14.47 & 39.1 \\
\hline Stew & 164.07 & 5.5 & 1.01 & 2.7 \\
\hline Vegetable Soup & 239.41 & 8.0 & 16.41 & 44.4 \\
\hline
\end{tabular}

*A male adult requires $2944 \mathrm{Kcal}$ of energy/day and $49 \mathrm{~g}$ of protein/day (WHO, 1985).

Proximate composition of cooked beans: The proximate composition of cooked beans collected at various locations in Abeokuta Township is presented in Table 2. The result indicated that the most abundant components of the cooked beans are water, carbohydrate and protein. Appreciable amount was also recorded for caloric value. The ash contents were generally low followed by the fat content. The moisture, carbohydrate and protein values 
obtained ranged from 68.0-69.4\%, 17.09-14.51\% and $11.0-12.3 \%$ respectively. The highest values of protein $(12.2 \%)$, fat $(0.55 \%)$ and energy content $(118.10 \mathrm{KCal}$.$) were recorded on$ samples obtained from Lafenwa/Ita-Oshin areas. The highest value of moisture $(69.40 \%)$ and carbohydrate $(17.09 \%)$ were recorded on samples obtained from Sapon/Itoku and Isabo/Kuto areas. This might be due to varietal differences of the cooked beans. Across the location, there were no appreciable differences in the proximate composition of the cooked beans sold to consumers.

Proximate composition of cooked Yam: The results of the proximate composition of cooked yam at different locations in Abeokuta are shown in Table 3. Cooked yam samples obtained at Omida/Ibara area has the highest moisture content of $68.22 \%$ whilst cooked yam from Isabo/Kuto area has the lowest value of moisture components of $67.22 \%$. Correspondingly, the highest (128.21 KCal) and lowest (124.12 KCal) amounts of energy contents were estimated in the samples obtained at Isabo/Kuto and Omida/Ibara areas respectively. The protein content ranged from $1.70-12.33 \%$ whilst the fat content ranged from $0.31-0.33 \%$ and the ash values ranged from 1.14-1.18\%. Cooked yam samples obtained at ijaiye/OkeIjeun area were found to be rich for its carbohydrate (20.56\%) and the lowest value of $28.06 \%$ were found in Omida/Ibara sample.

Cooked yam being a tuber crop showed higher amount of carbohydrate content with corresponding appreciable values of energy content. To soften the tuber during cooking, an appreciable amount of water is needed, hence higher value were also recorded for moisture content. Contrastingly, fat and protein contents were found to be low. Tubers are usually not a rich source of fat and even protein, hence the low values recorded for these nutrients can be understood in the tested cooked yam. In reference to the results, the proximate values obtained for cooked yams across the locations were uniform and less varied depicting similar trend in preparation techniques and selection of materials.

Proximate composition of cooked Fufu: A summary of the proximate composition of cooked fufu sold around Abeokuta township is indicated in Table 4. The results showed that a large part of cooked fufu samples consisted of water and carbohydrate. The values recorded for fat, protein and ash were considerably low. As a result, the energy content estimated for the samples were consequently low. The moisture content ranged from 77.78-65.83\%. The highest values of carbohydrate and energy contents were observed on the cooked fufu sold at Adatan/Asero area followed by that of Sapon/Itoku, Ijaye/Oke-ijeun samples. Whereas the lowest carbohydrate and energy contents were observed on cooked fufu sold at Kuto/Isabo area. In terms of location, though cooked fufu samples collected from Adatan/Asero location has highest value of the energy content (92.71 $\mathrm{KCal}$ ), this value and other energy contents were not appreciably different. The fat content of Cooked fufu in Omida/Ibara $(0.10 \%)$ was higher than those collected in other areas. This may be due to the fact that some processors add palm oil during the cooking of fufu.

Proximate Composition of fried fish: The results of the proximate composition of fried fish at different locations in Abeokuta are shown in Table 5. From the table, the fried fish has a high protein, fat, and ash content in the range of $35.63 \%, 14.23 \%$, and $5.04 \%$ for samples sold at Sapon/Itoku area. The high protein will enhance the prevention of low protein intake. The fried fish samples have a low carbohydrate and but high energy value $(384.31 \mathrm{KCal})$ because of high fat and protein content. Across the location, there were no appreciable differences in the proximate composition of the collected fried fish.

Proximate composition of stew: The results of the proximate composition of stew at different locations in Abeokuta are shown in Table 6. The result showed that stew composed abundantly of water, fat and ash. The moisture ranged from $71.05-72.64 \%$, fat ranged from 17.07-19.07\% whilst ash ranged from $8.63-8.87 \%$. The result also showed that tested stew was low in protein and carbohydrate content. In terms of locations, the highest value of moisture $(72.64 \%)$, fat $(19.07 \%)$ and ash $(8.87 \%)$ contents were found in stew sampled at Sapon/Itoku, Omida/Ibara respectively. In contrast, the highest value of protein $(1.03 \%)$ and carbohydrate $(0.86 \%)$ 
content were respectively found in samples obtained at Lafenwa/Itaoshin, Mokola/Iberekodo and Isabo/ Kuto areas respectively. The energy content of stew ranged from 160.27-172.86 KCal and this is quite an appreciable value. From the result, stew can be regarded as a food fairly high in energy because of its relatively high fat content. Across the locations, there was no appreciable difference amongst the values obtained. This is expected based on that fact that vendors employed almost same process of producing stew.

Proximate composition of vegetable soup: The results of the proximate composition of vegetable soup at different locations in Abeokuta are shown in Table 7. From the table, the vegetable soup has a high moisture, protein, fat, and ash content but less carbohydrate content. The moisture ranged from 45.39-46.92 \%, protein ranged from $18.54-19.34 \%$, fat ranged from $17.43-17.51 \%$ whilst ash ranged from 15.91-16.60\%. The result also showed that tested stew was low in carbohydrate content. In terms of locations, the highest value of moisture $(46.92 \%)$, protein $(19.34 \%)$, fat $(17.51 \%)$ and ash $(16.60 \%)$ contents were found in vegetable soup sampled at Mokol/Iberekodo, Lafenwa/ Itaoshin, Omida/Ibara, and Lafenwa/Itaoshin, respectively. In contrast, the highest value of carbohydrate (1.97\%) content was found in samples obtained at Omida/Ibara area. The energy content of vegetable soup ranged from 237.59-241.83 KCal and this is quite an appreciable value. From the result, vegetable soup can be regarded as a food fairly high in energy because of its relatively high fat content.

In terms of location, there were no appreciable differences in the proximate composition of the collected vegetable soups. This is expected as the responses of the vendors revealed that there is almost the same process of producing vegetable soup, with the exception of the use of soybean flour instead of traditional melon flour as a protein source.

\section{DISCUSSION}

Based on the result obtained from the proximate analysis, street foods sold in Abeokuta township can be regarded as good sources of basic nutrient which can meet the recommended dietary allowance of the consumers. A right combination of the street foods would serve as a means of obtaining a nutritionally balanced meals outside the home and subsequently meeting the required ration for body development. The data obtained showed that dishes based on cereals and tuber crops would serve as an important sources of energy while legumes would be a source of plant protein in the meal of street foods consumers. Supplementation with vegetables and animal foods will provide good levels of protein.

The mean energy and protein values present in the collected street foods are shown in Table 8 . WHO (1985) reported that a male adult requires $2944 \mathrm{KCal}$ of energy/day \& 49g of protein/day. Relating the values in Table 8 to the recommended daily intake of an adult Nigerian man revealed that consumption of a substantial quantity of the street foods as well as right combination of the foods can supply an appreciable amount of the recommended daily intake. For instance, consumption of about $700 \mathrm{~g}$ of cooked fufu with about $200 \mathrm{~g}$ of vegetable soup will provide $37 \%$ energy and $89.4 \%$ protein. Addition of fish or meat or both to the food will further enrich the intake of consumers. Street vended foods can thus serve as a strategy of eliminating malnutrition in urban and rural communities.

Conclusions and Recommendation: It could be observed in this study that nutritionally street foods provide appreciable nutrients and calories to the consumers. However the safety point of view of the selected street foods needs to be investigated before a final conclusion could be drawn.

\section{RESUMO}

Composição química de sete alimentos comuns; arroz cozido, feijão cozido, inhame cozido, fufu cozido, peixe frito, carne e sopa de verdura cozida, comercializadas por vendedores de Abeokut - Nigéria foram analisadas. Estatística descritiva foi usada para analisar os resultados obtidos. Os resultados da análise das amostras de 
alimento mostraram que o teor de umidade nos alimentos variou de $44.87 \%$ em peixe frito a $72.43 \%$ no fufu cozido. O conteúdo de proteína variou de $0.03 \%$ em fufu cozido a $14.47 \%$. em peixe frito, enquanto o teor de gordura variou de $0.03 \%$ no fufu cozido a $34.43 \%$ em peixe frito. $\mathrm{O}$ teor de cinzas e carboidratos variou de $0.42 \%$ em arroz cozido a $16.07 \%$ em sopa de verdura, e de $0.73 \%$ em carne cozida a $29.27 \%$ em arroz cozido, respectivamente. O Valor calórico variou de $89.0 \mathrm{Kcal}$ em fufu cozido a $375.24 \mathrm{Kcal}$ em peixe frito. Em geral, peixe frito apresentou valores altos em proteína (14.47\%), gordura (34.43\%) e valor calórico de (375.24 KCal.) Os resultados mostram que não havia diferenças significativas na composição dos alimentos selecionados em localidades próximas.

\section{REFERENCES}

Addo, A. A. (1998), Street foods in a depressed economy. Paper presented at the $22^{\text {nd }}$ Annual Conference of Nigerian Institute of Food Science and Technology (NIFST), University of Agriculture, Abeokuta 23-26 November

AOAC (1980), Official Methods of Analysis. 11th edition. Washington DC. Association of Analytical Chemists, USA

Food and Agriculture Organisation, FAO (1992), Report of Intercountry Workshop on Street
Foods in Africa, Accra, Ghana, 27 April-1 May

Food and Agriculture Organisation, FAO (1995), Street foods. Report of an FAO Technical Meeting on Street Foods. Calcutta, India, 6-9 November, 1995, pp. 76

Food and Agriculture Organisation, FAO (1997), Improving Nutrition and food security opportunities and challenges posed by street foods. Committee on World Food Security, Food and Agricultural organization, $23^{\text {rd }}$ Session, Rome, 15-18 April, 1997, pp. 11

Iwe, M. O. and Onuh, J. O. (1992), Functional and sensory properties of soyabean and sweet potato mixtures. Lebensmittel-Wissenchaft und-Tech 215, 569-573.

Oguntona, C. R. B. and Kanye, O. (1995), Contribution of street foods to nutrients intakes by Nigerian Adolescents. Nut.Health, 10: $165-171$

Oguntona, C. R. B., Razaq, M. A. and Akintola, T. T. (1998), Pattern of Dietary intake and consumption of street foods among Nigerian Students. Nutr. \& Health 12, 247-256

World Health Organization-WHO (1985), Energy and protein requirements. Report of aJoint FAO/WHO/UNU Expert Consultation. WHO Technical Reports Series No. 724. Geneva, Switzerland 